\title{
Neutrophil Extracellular Traps in Colorectal Cancer Progression and Metastasis
}

\author{
Umama Khan $^{1} \mathbb{D}$, Sabrina Chowdhury ${ }^{2}$, Md Morsaline Billah ${ }^{1} \mathbb{D}$, Kazi Mohammed Didarul Islam ${ }^{1} \mathbb{D}$, \\ Henrik Thorlacius ${ }^{3}$ and Milladur Rahman ${ }^{3, * \text { (D) }}$
}

1 Biotechnology and Genetic Engineering Discipline, Khulna University, Khulna 9208, Bangladesh; umamakhan140717@gmail.com (U.K.); morsaline@bge.ku.ac.bd (M.M.B.); didar950718@yahoo.com (K.M.D.I.)

2 Biochemistry and Biotechnology, North South University, Dhaka 1229, Bangladesh; sabrinaachowdhury6@gmail.com

3 Department of Clinical Sciences, Malmö, Section for Surgery, Lund University, 21428 Malmö, Sweden; henrik.thorlacius@med.lu.se

* Correspondence: milladur.rahman@med.lu.se

Citation: Khan, U.; Chowdhury, S.; Billah, M.M.; Islam, K.M.D.;

Thorlacius, H.; Rahman, M.

Neutrophil Extracellular Traps in Colorectal Cancer Progression and Metastasis. Int. J. Mol. Sci. 2021, 22, 7260. https://doi.org/10.3390/ ijms 22147260

Academic Editor: Carmine Stolfi

Received: 12 June 2021

Accepted: 2 July 2021

Published: 6 July 2021

Publisher's Note: MDPI stays neutral with regard to jurisdictional claims in published maps and institutional affiliations.

Copyright: (c) 2021 by the authors. Licensee MDPI, Basel, Switzerland. This article is an open access article distributed under the terms and conditions of the Creative Commons Attribution (CC BY) license (https:/ / creativecommons.org/licenses/by/ $4.0 /)$.

\begin{abstract}
Neutrophils form sticky web-like structures known as neutrophil extracellular traps (NETs) as part of innate immune response. NETs are decondensed extracellular chromatin filaments comprising nuclear and cytoplasmic proteins. NETs have been implicated in many gastrointestinal diseases including colorectal cancer (CRC). However, the regulatory mechanisms of NET formation and potential pharmacological inhibitors in the context of CRC have not been thoroughly discussed. In this review, we intend to highlight roles of NETs in CRC progression and metastasis as well as the potential of targeting NETs during colon cancer therapy.
\end{abstract}

Keywords: colorectal cancer; metastasis; neutrophil; extracellular DNA; therapeutics

\section{Introduction}

Colorectal cancer (CRC) is the second most common cause of cancer-related deaths in the western world [1]. Every year, the management of CRC imposes a huge economic burden towards the health care system in Europe and other countries in the world [2]. CRC originates from benign, precancerous proliferative growth known as polyps [3]. During the slow development phases of polyp, different mutations start to accumulate and transform some of the polyps into malignant carcinoma [3]. Early stages of CRC are curable by surgery, however, when cancer metastasizes to lymph nodes or other distant organs, the prognosis of CRC becomes poor [4]. Furthermore, about $20 \%$ of CRC patients have already progressed into a metastatic state at the time of presentation and more than $30 \%$ of patients with early CRC have been reported to develop metastatic disease eventually $[5,6]$. The most common site of CRC metastasis is found to be the liver (about $70 \%$ of patients), followed by lung, distant lymph nodes, and peritoneum [7]. Once CRC is metastasized to multiple organs, its treatment becomes palliative rather than curative. During metastasis, cancer cells express certain characteristics, which include elevated expression of cell adhesion molecules, chemokine receptors, and increased cytoskeletal changes to favor migration in response to chemotactic signals to distant organs [8-10].

Accumulating studies suggest that approximately $25 \%$ of all tumors originates from chronic inflammation [11-13]. It is possible that inflammation can generate numerous growth factors and chemo-attractants to promote cancer cell proliferation, adhesion, and migration. During innate immune response, neutrophils play a key role by engulfing the invading pathogens directly or releasing antimicrobial agents to kill them. Interestingly, the increased accumulation of neutrophils was observed in pre-metastatic organs $[14,15]$. In addition to phagocytosis, neutrophils can form sticky web-like structures of decondensed chromatin filaments, decorated with histones and neutrophil granule proteins 
known as neutrophil extracellular traps (NETs) [16]. NETs have been reported to be involved in cancer development [17-19] and metastasis [20,21]. A study has revealed the association of NET formation inside the microvasculature by systemic inflammation with trapping of cancer cells in both liver and lung [22]. In addition, intravascular NET increases vascular permeability and promotes cancer cell extravasation from blood vessels to organs [23]. Interestingly, surgical stress facilitates cancer metastasis through associating it with inflammation [24,25]. Furthermore, immunostaining of tissue samples from CRC patients revealed the presence of NETs in primary tumor and associated metastatic lymph nodes [26]. Based on this evidence, it could be suggested that NETs might be involved in colon cancer cell proliferation and metastasis. This review will focus on the roles of NETs in CRC progression and metastasis, as well as the possibility of targeting NETs during cancer therapy.

\section{Mechanism of NET Formation}

The process in which NET formation occurs is known as NETosis. Initially, NETosis was referred to as the new type of defensive neutrophil death, however, later it was found that pathogenic stimulation could also induce vital and rapid production of NETs without effecting neutrophil viability [27]. Two types of mechanism have been proposed to elucidate NET formation: NADPH-oxidase (NOX)-dependent lytic NET formation and NADPH-oxidase (NOX)-independent non-lytic NET formation [28] (Figure 1).

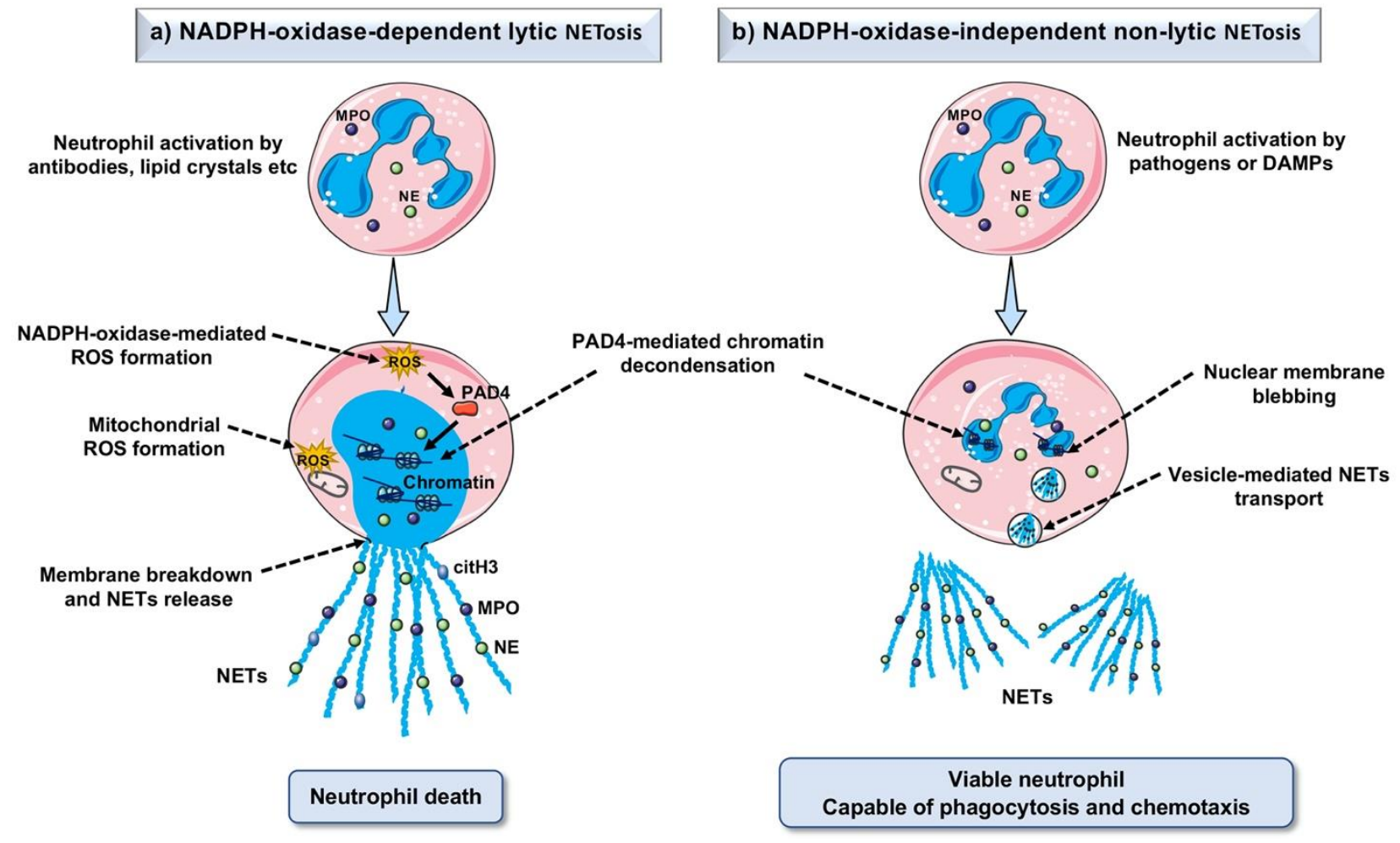

Figure 1. Mechanisms of NET formation. (a) NADPH-oxidase (NOX)-dependent lytic NET formation: After activation, neutrophils produce reactive oxygen species (ROS) via the NADPH-oxidase complex. ROS activates or upregulates proteinarginine deaminase type 4 (PAD4, which promotes citrullination of histones and subsequent chromatin de-condensation). Myeloperoxidase (MPO) helps translocate neutrophil elastase (NE) into the nucleus, which leads to further chromatin de-condensation, finally the nuclear membrane is disrupted, and NETs decorated with granular and cytosolic proteins are released in extracellular space. Neutrophils die after NET formation. (b) NADPH-oxidase (NOX)-independent non-lytic NET formation: After neutrophils activation by pathogens or DAMPs, PAD4 promotes chromatin de-condensation. NETs decorated with granular and cytosolic proteins are released outside via vesicular transport without plasma membrane disruption. After the release of NETs, neutrophils remain viable, and capable of phagocytosis and chemotaxis. 


\subsection{NADPH-Oxidase (NOX)-Dependent Lytic NET Formation}

The process of lytic NET formation initiates with the recognition of pathogens or sterile stimuli by various cellular receptors including toll-like receptors (TLRs), antibody fragment $(\mathrm{Fc})$ receptors, complement receptors, etc. [27]. The initial activation via cellular receptors triggers calcium release from endoplasmic reticulum (ER), which in turn activates protein kinase $\mathrm{C}(\mathrm{PKC})$ and NADPH-oxidase complex, finally forming reactive oxygen species (ROS) [29]. In particular, ROS can activate protein-arginine deiminase 4 (PAD4), an enzyme that decondenses nuclear chromatin by converting arginine to citrulline [30]. Furthermore, neutrophil granular protein, myeloperoxidase facilitates neutrophil elastase translocation to the nucleus and unfolds chromatin [31]. This results in the breakdown of nuclear membrane and the release of decondensed chromatin into cytosol where released DNA is further decorated with granular and cytosolic proteins [32]. Finally, NETs are released through disruption of the plasma membrane, and when the neutrophil dies. Interestingly, some studies showed that mitochondrial DNA could also be expelled as NETs in response to inflammation [33,34].

\subsection{NADPH-Oxidase (NOX)-Independent Non-Lytic NET Formation}

Several studies have revealed that the formation of NETosis is independent of cell death $[35,36]$. The process of NET formation without cell death is known as non-lytic or vital NETosis which usually occurs in the absence of NADPH-oxidase pathway and does not lead to the formation of oxidants [27]. The major difference between lytic and non-lytic NETosis is that non-lytic NETosis takes place within minutes of stimulation without ROS formation while lytic NETosis needs several hours of stimulation and ROS formation. In non-lytic NET formation, neutrophils activation is induced by bacteria or bacterial products or activated platelets or complement proteins [27]. Chromatin de-condensation and neutrophil elastase translocation to the nucleus take place in a similar manner to lytic NET formation. However, chromatin decorated with cytosolic and nuclear proteins is discharged by the blebbing nuclear envelope rather than the overt breakdown of the nuclear membrane. Nuclear membrane blebbing and vesicle-mediated extracellular transport of NETs occur independent of plasma membrane disintegration $[37,38]$.

\section{NETs in Gastrointestinal Inflammation}

NETs have been implicated in many gastrointestinal diseases including inflammatory bowel diseases (IBDs) [39-41], liver disease [35], and acute pancreatitis [42-44]. A chronic abiding repetitive event of inflammation in intestinal epithelium is portrayed as IBD [39]. Aberrant NET accumulation and the deterioration of inflamed intestinal barrier integrity can be correlated with IBD [39], as in ulcerative colitis (UC) [40]. Neutrophils and NETassociated molecules are found in abundance in both colonic biopsies of UC [45,46] and Crohn's disease (CD) [41], which indicate intestinal inflammatory aggravation, epithelial exasperation, and elevated thrombotic impulse [47]. Administration of dextran sulfate sodium (DSS) [36,46] or 2,4,6-trinitrobenzene sulfonic acid (TNBS) [40] can induce murine UC, principally by disrupting intestinal epithelial barrier and eliciting a number of chronic immunologic responses. In the mouse model, increased DSS consumption can elevate the plasma level of extracellular DNA (ecDNA) in the form of NETs, which in turn induces UC [39]. The elevated response is correlated with the amplitude of disease severity and relative proportion of cells undergoing NETosis. However, the initial administration of protein-arginine deaminase type 4 (PAD4) inhibitors, $\mathrm{Cl}$-amidine and streptonigrin can curb the formation of NETs, and in turn decrease the plasma ecDNA level in UC [39]. Some other studies have reported that the systemic administration of DNase can lead to amelioration of DSS-induced colitis by dissolving NETs $[39,47]$. In addition, the elevated level of NETinducing protein, PAD4 is found in colon biopsies of active UC and CD cases compared to healthy patient samples [46]. The detrimental consequence of abnormal NET formation can lead to intestinal laceration and mortality, which can be curtailed by inhibiting PAD4 in a murine model of necrotizing enterocolitis $[48,49]$. Severe inflammation, intestinal 
necrosis, ulceration, as well as NET formation can be detected by light and fluorescence microscopy in the specimen of colonic resection from drug-crystal induced gastrointestinal complications [50]. In addition, NETs can produce numerous pro-inflammatory granular proteins, which may indirectly evoke the inflammation of local intestinal mucosa and eventually cause necroinflammation [51,52].

NETs also elicit a detrimental immune response leading to IBD through the production of neutrophil-driven granular proteins, including NE, MPO, histones, cathepsin G, and proteinase 3 (PR3), which can promote anti-neutrophil cytoplasmic auto-antibodies (ANCAs) production [53]. ANCAs are known to activate, complement, and cause endothelial damage [54]. In addition, they are also reported to generate a positive pro-inflammatory feedback loop by inducing NET formation [55]. Moreover, several studies have reported the presence of ANCA in serum of patients with IBD and/or in a murine model, which may be triggered by dendritic cells or MPO or PR3 [56,57]. In contrast, a recent review proposed beneficial roles of NETs in IBD [58]. Authors indicated favorable roles of circulating NETs in clearing damage associated molecular patterns based on previous studies [59-61]. However, none of these studies were conducted on NETs. In fact, they investigated the possible effects of bacterial DNA (bactDNA) and translocation of gut bacteria in IBD [59-61]. Since various gastrointestinal inflammation and diseases have been shown to be correlated with NET formation and NETs can be reciprocally related with an increased risk of developing intestinal malignancies, further studies are required to explore the axis of gastrointestinal inflammation and CRC in the context of NETs.

\section{NETs in Cancer Progression and Metastasis}

Over the years, NETs have been implicated in various types of cancer where they are involved in cancer growth or clearance, depending on cancer type, status of the immune system or tumor microenvironment $[20,27]$. Interestingly, higher levels of plasma NETs are present in cancer patients including lung, pancreatic, and bladder cancer [62]. In addition, NETs are found in lung tissues, serum, and sputum of lung cancer patients [63]. In the mice model, installation of cancer cells in the lung induces neutrophil recruitment and NET formation, suggesting that cancer cells itself can induce NET formation, perhaps by facilitating cancer cells adhesion and growth. Higher levels of NETs were observed in the liver metastases of patients with breast cancer, and serum NETs were identified as a predictive marker for the onset of liver metastases in patients with early-stage breast cancer [64]. In addition, it was revealed that CCDC25, a transmembrane protein, of breast cancer cells have the ability to sense distant NETs and navigate cancer cells to NETs [64]. An in vitro experiment has shown that NETs can induce breast cancer cells invasion and migration, and subsequent digestion of NETs by DNase I-coated nanoparticles reduces metastasis of breast cancer cells to lung in mice [65].

NET formation is observed during lung inflammation induced by smoke exposure or nasal instillation of lipopolysaccharide in animal models. NET associated proteases, neutrophil elastase, and matrix metalloproteinase 9, can cleave basal laminin and thus facilitate dormant cancer cells growth by activating integrin alpha-3 beta- 1 signaling [66]. NETs can act as a trap to catch circulating cancer cells in the microvasculature of distant organs. In a murine model of sepsis, circulating lung carcinoma cells are reported to be trapped by NETs in the microvasculature of liver and cause gross metastatic burden after injection of tumor cells [22]. In addition, treatment with DNase or a neutrophil elastase inhibitor reduces cancer metastasis [22]. CD16 ${ }^{\text {high }}$ and $\mathrm{CD} 62^{\text {low }}$ neutrophil subpopulation possess higher NETs producing capacity and in head and neck squamous cell carcinoma patients, this subpopulation shows better survival [67]. Another study indicates that tumors can release granulocyte colony-stimulating factors into the bloodstream and promote the accumulation of intratumoral NETs and tumor growth by priming circulating neutrophils [68].

In gastric cancer (GC), the analysis of blood samples has revealed higher levels of NETs in patients with benign gastric disease than healthy controls [69]. The results indicate a better diagnostic value of NETs than carcinoembryonic antigen (CEA) and carbohydrate 
antigen 19-9 (CA19-9). These findings suggest the pivotal roles of NETs in the carcinogenesis of GC. In another study, it has been reported that low density neutrophils (LDN) from postoperative lavage generate a massive amount of NETs during the in vitro culture. In addition, the co-transfer of the peritoneal LDN with human gastric cancer cells enhance peritoneal metastasis in vivo [70].

\section{COVID-19 and Cancer Progression}

In recent times, due to the prevalence of ongoing worldwide COVID-19 pandemic, a considerable scientific interest has grown to determine the interdependence of COVID-19 in cancer progression and investigation of increased risk for potential and life-threatening outcomes from COVID-19 infections in the underlying medical condition of cancer. A recent systematic review involving 52 studies on COVID-19 and cancer has revealed that patients with cancer have a high probability of mortality due to the severe acute respiratory syndrome coronavirus 2 (SARS-CoV-2) [71]. One of the studies has indicated the presence of NETs in the lungs of autopsied COVID-19 patients [72], while another report has demonstrated the role of NETs in the initiation of immunothrombosis in COVID-19 patients [73]. It has been found that cancer patients could be more susceptible to SARSCoV-2 infections due to the immunosuppression caused by chemotherapy or cancer itself. Furthermore, a meta-analysis has revealed that lung cancer and CRC patients are most susceptible to SARS-CoV-2 infection over other cancer types including breast, esophagus, bladder, pancreatic, and cervical cancer [74]. It is well documented that the expression of Angiotensin I-converting enzyme 2 (ACE2) on pulmonary epithelial cell plays the vital role in entering the virus into the body and interestingly, the expression of ACE2 is found to be higher in CRC tissues than matched normal tissues [75]. Furthermore, a higher expression of ACE2 has been observed in lung metastases from CRC than in normal lungs, suggesting that CRC patients are more vulnerable to SARS-CoV-2 infection [75]. The SARS-CoV-2 infection can be related to cancer pathogenesis as the progression of infection can alter the expression of the proteins involved in cell-cycle checkpoints, metabolism, and epigenetic regulation [76]. On the other hand, as hypoxia due to the SARS-CoV-2 infection can lead to poor oxygen supply to different organs, it can alter cancer cell metabolism and promote epithelial to mesenchymal transition [77]. For example, in breast cancer, hypoxia has been shown to promote gene expression involved in dormancy and drug resistance [78,79]. An alternative mechanism of cancer progression and metastasis during or after SARS-CoV-2 infection has been proposed, which indicates lowering of natural killer cells and $\mathrm{T}$ cells in the peripheral blood [80]. Taken together, it is our speculation that NET formation and lung inflammation by SARS-CoV-2 infection might trigger colon cancer cell migration and adhesion to inflamed organs.

\section{NETs in Colorectal Cancer}

Several studies have confirmed that patients with CRC can release elevated levels of NETs both in vivo and in vitro $[25,81,82]$, which are mostly dispersed within the primary tumor sites and over the tumor boundary of CRC [26]. Although chemoradiotherapies and screening programs for early CRC detection are universal, about half the patients undergoing resection with therapeutic resolution tend to develop metastatic illness [83]. Accumulating evidences suggest that preoperative systemic inflammation could be involved in CRC recurrence following surgical resection [84]. In addition, several murine models and human observational studies demonstrated potential prognostic significance and association of NETs with CRC progression [84]. The recurrence and metastasis can be correlated with NETs production by perioperative systemic inflammation, such as sepsis or NETs production on the site of surgical wounds.

Several mechanisms have been proposed that can trigger NET formation in the CRC microenvironment (Figure 2). For instance, polyphosphate (polyP) expressed by CD68+ mast cells are shown to stimulate neutrophils to produce NETs in human colon carcinoma ex vivo [85]. KRAS, a small G protein of RAS family acts as a molecular switch 
in signal transduction pathways [86]. Activation of mutated KRAS regulates oncogenic malignant transformation and subsequent proliferation of cancer cells through activation of RAS/MAPK signaling pathway [82,87,88]. In $40-50 \%$ of CRC cases, KRAS mutations have been documented, hence, several studies have acknowledged it as a potential CRC prognostic and predictive marker [87,89]. Malignant cells can secrete exosomes to control the cellular microenvironment and KRAS mutant CRC cells have been shown to transfer mutant KRAS to neutrophils via exosomes [82]. The transfer of KRAS mutant protein by CRC cells induces neutrophil recruitment and subsequent NET formation by the upregulation of interleukin-8 (IL-8/CXCL8) both in vivo and in vitro [82]. The production of elevated levels of IL-8 and NET formation can act as a stimulator of CRC cell proliferation and can ultimately worsen the cancer condition [82]. IL-8 is known to recruit neutrophils and other myeloid leukocytes to converge at the site of infection via its receptors CXCR1 and CXCR2 [90,91]. IL-8 acts as a multifaceted chemotactic stimulus utilized by neoplastic cells to foster transmigration and angiogenesis concurrently [92,93]. Tumor cell-driven expression and excretion of IL-8 can also augment proliferation and survival of cancer cells by activating the autocrine system, promoting angiogenesis and infiltrating neutrophils into the malignant cells $[90,91,94]$. There is a clear correlation between IL-8 and NETosis in cancer progression and IL-8 mainly abets cancer progression, metastatic spread, and angiogenesis by directly priming the NET formation [82,90]. IL-8 along with its receptor CXCR2 is observed to provoke neutrophils towards the release of NETs by activating Src, ERK, and p38 signaling and the resultant released NETs can directly upregulate TLR9 pathways to stimulate cancer progression [95]. Moreover, IL-8 stimulates myeloid-derived suppressor cells via expressing CXCR1 and CXCR2 on their surfaces to extrude NETs which are shown to entrap cancerous cells [92]. Additionally, serum levels of IL-8 and its receptor CXCR2 are shown to highly upregulate in different phases of CRC compared to the normal samples. The secreted IL-8 profoundly stimulates human and murine CRC cell proliferation, incursion, migration, and amplifies angiogenesis around the tumor [91]. Moreover, IL-8-stimulated neutrophil-extruded NETs further advance the invasion and proliferation of CRC [91]. Lesions of CRC show a divergent surge of IL- 8 where the upregulated IL-8 induces the activation of neutrophils and NET formation in CRC microenvironment [91,94].

It has been found that NET formation not only increases CRC cells proliferation but also stimulates the metastasis process [94,96]. NETs prime circulating tumor cells (CTC) adherence to hepatic or pulmonary endothelial surfaces $[89,96,97]$ and thus, are involved in increased migratory pattern of CRC cells to the major critical regions of the body, such as liver, lung, and peritoneal cavity $[25,96,98]$. Surgical interventions for CRC are known to promote peritoneal carcinomatosis [99]. In fact, a recent study in mouse has shown that surgical trauma promotes colon cancer cells adhesion and growth in the peritoneal wall via CXCR2 signaling [100]. Population-based researches have reported that about $25-30 \%$ of CRC patients develop coetaneous liver metastasis and most of them show remarkably increased NET formation $[25,96,101]$. NETs show no cytotoxicity to the trapped CTCs in the liver but can raise their malignancy by enriching tumorous interleukin (IL-8) which in turn primes more NET formation, hence creating a positive loop for liver metastasis [94]. Furthermore, NET-associated carcinoembryonic antigen-related cell adhesion molecule 1 (CEACAM1) has been shown to stimulate the relocation of CRC cells to the liver both in vitro and in vivo [102].

A cohort of patients with analeptic liver resection for metastatic colorectal cancer has demonstrated the association of elevated postoperative NET formation with a lower survival rate [25]. In the same study, in a mouse model of liver metastasis and surgical stress, it has been shown that the inhibition of NET formation by DNase I reduces postoperative development of gross metastases [25]. Furthermore, several other studies demonstrate that diminishing of NETs using DNase reduces metastatic progression of CRC [82,94,101,102]. Table 1 summarizes the major outcomes of the studies describing NETs in CRC. 


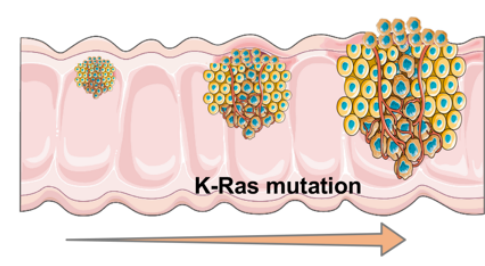

Progression of CRC

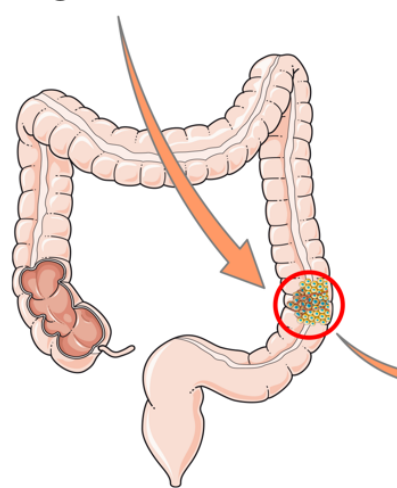

Cancer cells trapping in the blood vessel of distant organs

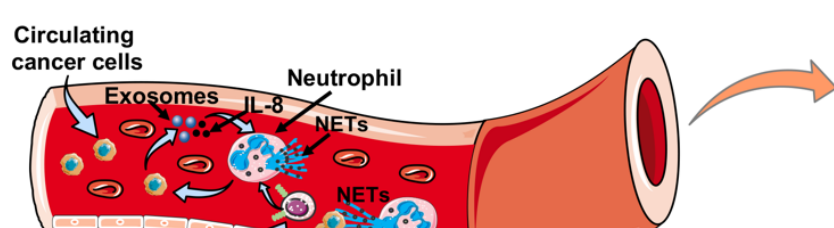
blood vessel

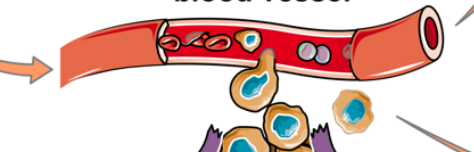

Dissemination of cancer cells towards surgical trauma or inflammation

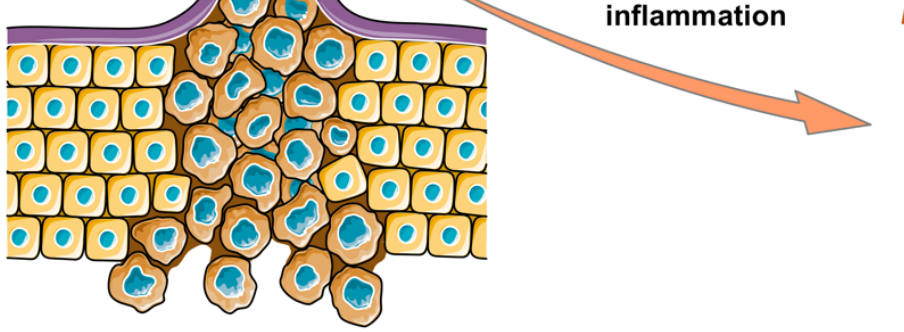

Multi-organ metastases

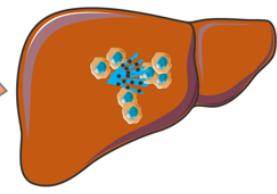

Liver metastases

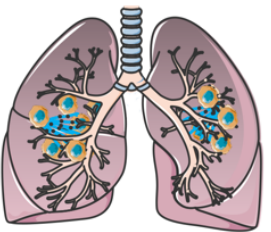

Lung metastases

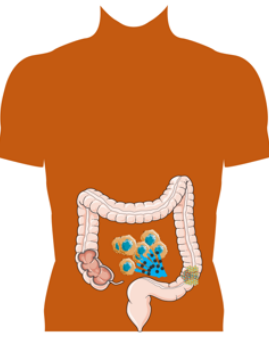

Peritoneal metastases

Figure 2. NET-mediated CRC progression and metastasis. KRAS mutation induces colon cancer cells proliferation and migration through the blood vessel. IL-8 secretion by circulating cancer cells or transfer of mutant KRAS to neutrophils via exosomes provoke NET formation in blood vessel of distant organs. Mast cells expressing polyphosphates (polyP) stimulate neutrophils and produce NETs. NETs trap cancer cells in distant organs such as in the liver and lung and thus, help metastatic spread. Spontaneous dissemination of colon cancer cells towards peritoneal wounds or inflammation and subsequent attachment to the inflamed peritoneum promote peritoneal metastases.

Table 1. Summary of the included studies of NETs in CRC.

\begin{tabular}{|c|c|c|c|c|}
\hline Study Design & Animal Models & Cell Type & Major Outcomes/Findings & Authors \\
\hline $\begin{array}{l}\text { Both in vivo } \\
\text { and in vitro }\end{array}$ & Mouse & $\begin{array}{l}\text { Human colon carcinoma } \\
\text { cell line (HT-29), murine } \\
\text { colon carcinoma }\end{array}$ & $\begin{array}{l}\text { NET-associated protein CEACAM1 is } \\
\text { an inducer of metastatic progression } \\
\text { of CRC and blocking of NETs } \\
\text { significantly reduce CRC cell } \\
\text { adhesion, migration, and metastasis in } \\
\text { murine model. }\end{array}$ & Rayes et al. [102] \\
\hline $\begin{array}{l}\text { Both in vivo } \\
\text { and in vitro }\end{array}$ & Mouse & $\begin{array}{l}\text { DKs-8 (WT allele) cells, } \\
\text { DKO-1 (KRAS mutant) } \\
\text { cells }\end{array}$ & $\begin{array}{l}\text { Exosomes from KRAS mutant CRC } \\
\text { increase IL- } 8 \text { production and provoke } \\
\text { NET formation. Released NETs } \\
\text { increase CRC cells growth both } \\
\text { in vivo and in vitro. }\end{array}$ & Shang et al. [82] \\
\hline $\begin{array}{l}\text { In vivo, in vitro, } \\
\text { and ex vivo }\end{array}$ & $\begin{array}{l}\text { Human and } \\
\text { Mouse }\end{array}$ & $\begin{array}{l}\text { Human hepatocellular } \\
\text { carcinoma, human } \\
\text { cell line HT29, and mice } \\
\text { cell line MC } 38\end{array}$ & $\begin{array}{l}\text { NETs raised colorectal malignancy by } \\
\text { enriching tumorous interleukin IL-8, } \\
\text { which in turn induce more NET } \\
\text { production by creating a positive loop } \\
\text { along with advancing CRC-driven } \\
\text { liver metastasis. Digestion of NETs by } \\
\text { DNase I reduced liver metastasis. }\end{array}$ & Yang et al. [94] \\
\hline
\end{tabular}


Table 1. Cont.

\begin{tabular}{|c|c|c|c|c|}
\hline Study Design & Animal Models & Cell Type & Major Outcomes/Findings & Authors \\
\hline $\begin{array}{l}\text { Both in vivo } \\
\text { and in vitro }\end{array}$ & Mouse & $\begin{array}{l}\text { Human hepatoma } \\
\text { cell line HepG2, murine } \\
\text { colon carcinoma MC38 }\end{array}$ & $\begin{array}{l}\text { Neutrophil infiltration and NET } \\
\text { formation reduced by } \\
\text { adeno-associated virus (AAV) based } \\
\text { DNase I gene therapy and reduced } \\
\text { liver metastasis in a mouse model of } \\
\text { CRC liver metastasis. }\end{array}$ & Xia et al. [101] \\
\hline $\begin{array}{l}\text { Both in vivo } \\
\text { and in vitro }\end{array}$ & Mouse & $\begin{array}{l}\text { Murine Lewis Lung } \\
\text { carcinoma cell subline H59, } \\
\text { Murine colon carcinoma } \\
\text { cell line MC38 }\end{array}$ & $\begin{array}{l}\text { Primary colon cancer cells provoked } \\
\text { NETs generation that prime adhesion } \\
\text { of CTCs to the liver and degradation } \\
\text { of NETs decreased CRC cell adhesion } \\
\text { and spontaneous metastasis to the } \\
\text { liver and lung. }\end{array}$ & Rayes et al. [96] \\
\hline $\begin{array}{l}\text { Both in vivo } \\
\text { and ex vivo }\end{array}$ & $\begin{array}{l}\text { Human and } \\
\text { Mouse }\end{array}$ & $\begin{array}{l}\text { Murine colorectal (MC38) } \\
\text { cells, } \\
\text { HCT116, Hepa1-6, and } \\
\text { Huh7 cell lines }\end{array}$ & $\begin{array}{l}\text { Patients undergoing curative resection } \\
\text { with colorectal metastases to the liver } \\
\text { showed an elevated level of NET } \\
\text { formation. Increased citrullinated } \\
\text { histones and circulating MPO-DNA } \\
\text { levels were related to poor survival of } \\
\text { CRC patients. }\end{array}$ & Yazdani et al. [98] \\
\hline Ex vivo & Human & CRC cells & $\begin{array}{l}\text { CD68+ mast cells expressed } \\
\text { polyphosphates (PolyP) in colorectal } \\
\text { adenomas and/or carcinomas and } \\
\text { suggested that CD68+ PolyP } \\
\text { expressing mast cells could be used as } \\
\text { prognostic marker. }\end{array}$ & Arelaki et al. [85] \\
\hline
\end{tabular}

Systemic neutrophils isolated from the CRC patients showed higher levels of NETs producing ability than healthy Ex vivo Human / controls in vitro. In vitro increased NET production is correlated with

Richardson et al. [81] patients' major complications than minor complications.

Neutrophils isolated from patients undergoing resectional surgery for CRC showed lower NET forming ability in vitro than preoperative

Richardson et al. [103] neutrophils.

Confirmed presence of NETs within the primary tumor sites of CRC and gradually dispersed to the tumor boundary, particularly to nearby

Arelaki et al. [26] metastatic lymph nodes.

Increased postoperative NETs generation after curative liver resection of colorectal metastasis patients. NETs further fuel the metastasis condition and reduce more than 4 -fold disease free survival.

\section{Therapeutic Potential of Targeting NETs in CRC}

Accumulating evidence suggest that cancer pathology is correlated with NET formation. Until now, many therapeutic agents targeting NETs or NET formation or NETassociated components are successfully used in clinic and experimental diseases. It is our expectation that some of these agents could be useful to mitigate CRC progression 
and metastasis. For instance, several studies have successfully utilized DNase to degrade DNA backbone of NETs in different types of diseases including cystic fibrosis [104], colitis [39,105], IBD [47], CRC [82,94,101,102], breast cancer [65], and pancreatic cancer [106]. A recent meta-analysis of Cochrane Cystic Fibrosis and Genetic Disorders Group Trials Register reveals that the use of aerosolized recombinant DNase enzyme (Pulmozyme) improves the lung function with patients with cystic fibrosis compared to the placebo [107]. The DNase treatment effectively reduces viscoelasticity of DNA released by neutrophil with improved pulmonary function and well-being of patients. One advantage of using DNase is that the DNase-mediated NETs digestion does not hamper the physiological functions of neutrophils $[28,108]$. Furthermore, long before NETs were discovered several studies reported that DNA could act as a protective shield for harmful proteases [109,110]. Thus, elimination of DNA structure might neutralize the activity of NET-associated harmful proteases and enzymes and protect organs from damage and inflammatory events. In contrast, one recent study has reported the failure of DNase to eliminate NET associated harmful proteases or histones [108], which are known to cause tissue damage [111].

In addition to targeting NETs by DNase, alternative novel approaches targeting NETosis have been shown to reduce NET formation in several preclinical inflammatory disease models. For example, inhibition of ROS [112-114], PAD4 [39,115,116], NO/NOS [117], and Gasdermin D [118], have shown to reduce NETosis and/or disease progression. ROSdependent formation of NET activates several sets of kinases (e.g., PKC, ERK, p. 38) via the activation of transcription factors (TFs), which in turn enables de-condensation of chromatin by PAD4 $[28,35]$. The inhibition of TFs does not hamper the immunological function of neutrophils but inhibits NET formation [112], thus it could be a suitable therapeutic approach to reduce NET-mediated CRC progression and metastasis. Moreover, the administration of PAD4 inhibitors (Cl-amidine and streptonigrin) showed promising therapeutic effects in DSS-induced UC [39]. Furthermore, the treatment with a high-affinity monoclonal antibody (infliximab) to TNF- $\alpha$, diminishes the expression of PAD4 and TNF$\alpha$-driven NETosis in UC [46], suggesting that infliximab could also be used as a potential therapy targeting NETs in CRC. Gasdermin D (GSDMD) is a pore forming protein that facilitates NETs extrusion by puncturing granules which can be inhibited by employing a tiny size particle based on the pyrazolo-oxazepine scaffold that competently halts NETosis [118]. A NET-driven granular protein MPO has also been investigated as a target of anti-NETosis therapy. The inhibition of MPO has shown to lessen neutrophil recruitment and NETosis in the murine model of vasculitis and in vitro experiments [119,120]. Higher levels of inducible nitric oxide synthase (iNOS) expression and activity were detected in colon cancer specimens as compared to normal mucosa $[121,122]$ and the use of NOS inhibitors together with 5-fluorouracil has shown enhanced reduction of colon cancer cells proliferation and migration [123]. Notably, the inhibition of NOS has shown to reduce nitric oxide (NO)-mediated NET formation in vitro [117], suggesting that the NOS inhibitor could also be used as a potential therapy in CRC management. Interestingly, metformin, a well-known clinically established antidiabetic drug, has been reported to reduce NET formation via the inhibition of PKC-NADPH-oxidase pathway [34,124]. In addition, the nanocarrier based combination treatment, such as Oshadi D (DNase in an Oshadi carrier) and Oshadi R (RNase in an Oshadi carrier), has shown promising anti-cancer effects in phase II clinical trial (ClinicalTrials.gov Identifier: NCT02462265), possibly by targeting NETs. Autophagy inhibitor, hydroxychloroquine, was also shown to reduce NET-mediated hepatic ischemia/reperfusion (I/R) injury by inhibiting PAD4 and Rac2 expression [125]. It should be noted that neutrophil plays a key role in innate immune response, therefore, targeting NETs or mechanisms of NETosis or NET-driven products should be implemented in such a way that the intervention should insulate the fundamental physiological function of neutrophils. Table 2 summarizes studies and therapeutics used to target NETs in various diseases. 
Table 2. List of studies targeting NETs in various diseases.

\begin{tabular}{|c|c|c|c|c|c|}
\hline Studies & Therapeutic Agents & Targets & $\begin{array}{l}\text { Mechanism of } \\
\text { Action }\end{array}$ & Major Findings & Disease/Model \\
\hline Yang et al. [94] & DNase 1 & $\begin{array}{l}\text { DNA backbone of } \\
\text { NETs }\end{array}$ & Digestion of NETs & $\begin{array}{l}\text { Diminished colorectal cancer } \\
\text { liver metastasis. }\end{array}$ & CRC (in vivo) \\
\hline Xia et al. [101] & $\begin{array}{l}\text { Adeno-associated } \\
\text { virus } \\
\text { (AAV)-mediated } \\
\text { gene transfer of } \\
\text { DNase I }\end{array}$ & $\begin{array}{l}\text { DNA backbone of } \\
\text { NETs }\end{array}$ & Digestion of NETs & $\begin{array}{l}\text { Reduced liver metastasis in a } \\
\text { mouse model of CRC liver } \\
\text { metastasis. }\end{array}$ & CRC (in vivo) \\
\hline \multirow{2}{*}{$\begin{array}{l}\text { Rayes et al. } \\
\text { [102] }\end{array}$} & DNase & $\begin{array}{l}\text { DNA backbone of } \\
\text { NETs }\end{array}$ & Digestion of NETs & \multirow{2}{*}{$\begin{array}{l}\text { Inhibited CRC cell adhesion } \\
\text { and migration in vitro. } \\
\text { Reduced liver metastasis of } \\
\text { CRC cells. }\end{array}$} & \multirow{2}{*}{$\begin{array}{l}\text { CRC (in vivo and } \\
\text { in vitro) }\end{array}$} \\
\hline & $\begin{array}{l}\text { CEACAM1 blocking } \\
\text { antibody }\end{array}$ & $\begin{array}{l}\text { NET-associated } \\
\text { CEACAM1 }\end{array}$ & $\begin{array}{l}\text { Blocking of } \\
\text { CEACAM1 on NETs }\end{array}$ & & \\
\hline $\begin{array}{l}\text { Shang et al. } \\
\text { [82] }\end{array}$ & DNase & $\begin{array}{l}\text { DNA backbone of } \\
\text { NETs }\end{array}$ & Degradation of NETs & $\begin{array}{l}\text { Reduced KRAS mutant } \\
\text { exosome-induced CRC cells } \\
\text { adhesion. }\end{array}$ & CRC (in vitro) \\
\hline $\begin{array}{l}\text { Shah et al. } \\
\text { [104] }\end{array}$ & DNase & $\begin{array}{l}\text { DNA backbone of } \\
\text { NETs }\end{array}$ & Degradation of NETs & $\begin{array}{l}\text { Reduced viscoelasticity of } \\
\text { sputum and improved } \\
\text { pulmonary function. }\end{array}$ & $\begin{array}{l}\text { Cystic fibrosis } \\
\text { (clinical trials) }\end{array}$ \\
\hline Li et al. [47] & DNase & $\begin{array}{l}\text { DNA backbone of } \\
\text { NETs }\end{array}$ & Degradation of NETs & $\begin{array}{l}\text { Lessened cytokine levels, } \\
\text { attenuated thrombus } \\
\text { formation and activation of } \\
\text { platelet. }\end{array}$ & $\begin{array}{l}\text { DSS-induced colitis } \\
\text { (in vivo) }\end{array}$ \\
\hline Park et al. [65] & DNase & $\begin{array}{l}\text { DNA backbone of } \\
\text { NETs }\end{array}$ & Degradation of NETs & $\begin{array}{l}\text { Inhibited NET-induced } \\
\text { invasion and migration of } \\
\text { breast cancer cells in vitro. } \\
\text { Reduced breast cancer cells } \\
\text { metastasis to lung. }\end{array}$ & $\begin{array}{l}\text { Breast cancer } \\
\text { (in vitro and } \\
\text { in vivo) }\end{array}$ \\
\hline Xiao et al. [126] & $\begin{array}{l}\text { AZD7986 (inhibitor } \\
\text { of Cathepsin C) }\end{array}$ & Cathepsin C & $\begin{array}{l}\text { Inhibit } \\
\text { CTSC-PR3-IL-1 } \beta \text { axis } \\
\text { mediated reactive } \\
\text { oxygen species } \\
\text { production }\end{array}$ & $\begin{array}{l}\text { Reduced lung metastasis of } \\
\text { breast cancer in a mouse } \\
\text { model. }\end{array}$ & $\begin{array}{l}\text { Breast cancer } \\
\text { (in vivo) }\end{array}$ \\
\hline Wen et al. [106] & DNase & $\begin{array}{l}\text { Extracellular DNA } \\
\text { (exDNA) }\end{array}$ & $\begin{array}{l}\text { Degradation of } \\
\text { exDNA }\end{array}$ & $\begin{array}{l}\text { Suppressed metastasis of } \\
\text { pancreatic cancer cells in an } \\
\text { orthotopic xenograft model. }\end{array}$ & $\begin{array}{l}\text { Pancreatic cancer } \\
\text { (in vivo) }\end{array}$ \\
\hline $\begin{array}{l}\text { Sollberger et al. } \\
\text { [118] }\end{array}$ & $\begin{array}{l}\text { Gasdermin D } \\
\text { Inhibitor (LDC7559) }\end{array}$ & $\begin{array}{l}\text { Pore-forming protein } \\
\text { Gasdermin D } \\
\text { (GSDMD) }\end{array}$ & $\begin{array}{l}\text { LDC7559 binds to } \\
\text { GSDMD and } \\
\text { prevents pore } \\
\text { formation in granule } \\
\text { membrane }\end{array}$ & $\begin{array}{l}\text { Decreased phorbol } \\
\text { 12-myristate 13-acetate } \\
\text { (PMA)-induced NET } \\
\text { formation. }\end{array}$ & In vitro \\
\hline $\begin{array}{l}\text { Khan et al. } \\
\text { [112] }\end{array}$ & $\begin{array}{l}\text { Actinomycin D and } \\
\text { Topoisomerase I } \\
\text { inhibitor }\end{array}$ & $\begin{array}{l}\text { Promoter region of } \\
\text { DNA }\end{array}$ & $\begin{array}{l}\text { Inhibit protein } \\
\text { transcription } \\
\text { initiation }\end{array}$ & $\begin{array}{l}\text { Blocking of transcription } \\
\text { suppresses NETosis without } \\
\text { affecting ROS generation. }\end{array}$ & In vitro \\
\hline \multirow{3}{*}{$\begin{array}{l}\text { Lood et al. } \\
{[113]}\end{array}$} & MitoTEMPO & ROS & $\begin{array}{l}\text { MitoTEMPO } \\
\text { scavenge } \\
\text { mitochondrial } \\
\text { superoxide }\end{array}$ & $\begin{array}{l}\text { Mitochondrial ROS inhibition } \\
\text { reduced NET formation and } \\
\text { systemic lupus } \\
\text { erythematosus (SLE) disease } \\
\text { severity. }\end{array}$ & \multirow{3}{*}{$\begin{array}{l}\text { SLE (in vivo and } \\
\text { in vitro) }\end{array}$} \\
\hline & Apocynin & ROS & $\begin{array}{l}\text { Block superoxide } \\
\text { production }\end{array}$ & $\begin{array}{l}\text { Reduced PMA-induced NET } \\
\text { formation. }\end{array}$ & \\
\hline & VAS2870 & ROS & $\begin{array}{l}\text { Inhibit } \\
\text { NADPH-oxidase } \\
\text { (NOX) }\end{array}$ & $\begin{array}{l}\text { Reduced PMA-induced NET } \\
\text { formation. }\end{array}$ & \\
\hline $\begin{array}{l}\text { Van Avondt } \\
\text { et al. [114] }\end{array}$ & $\begin{array}{l}\text { Diphenyleneiodonium } \\
\text { (DPI) }\end{array}$ & NADPH-oxidase & $\begin{array}{l}\text { Inhibit ROS } \\
\text { generation }\end{array}$ & $\begin{array}{l}\text { Reduced PMA-induced NET } \\
\text { formation. }\end{array}$ & In vitro \\
\hline
\end{tabular}


Table 2. Cont

\begin{tabular}{|c|c|c|c|c|c|}
\hline Studies & $\begin{array}{l}\text { Therapeutic } \\
\text { Agents }\end{array}$ & Targets & Mechanism of Action & Major Findings & Disease/Model \\
\hline Knight et al. [115] & $\begin{array}{l}\text { Cl-amidine and } \\
\text { BB-Cl-amidine }\end{array}$ & PAD4 & Inhibit PAD4 & $\begin{array}{l}\text { PAD inhibition diminished } \\
\text { NET formation and showed } \\
\text { protection against } \\
\text { lupus-related damage to } \\
\text { vasculature, kidney in murine } \\
\text { lupus model. }\end{array}$ & SLE (in vivo) \\
\hline Maronek et al. [39] & $\begin{array}{l}\mathrm{Cl} \text {-amidine and } \\
\text { Streptonigrin }\end{array}$ & PAD4 & Inhibit PAD4 & $\begin{array}{l}\text { Reduced plasma level of } \\
\text { ecDNA but could not } \\
\text { lessened total UC condition in } \\
\text { mice. }\end{array}$ & $\begin{array}{l}\text { DSS-induced UC } \\
\text { (in vivo) }\end{array}$ \\
\hline Dinallo et al. [46] & $\begin{array}{l}\text { Infliximab } \\
\text { (anti-TNF- } \alpha \\
\text { antibody) } \\
\end{array}$ & TNF- $\alpha$ & Block TNF- $\alpha$ & $\begin{array}{l}\text { Reduced PAD4 expression } \\
\text { and TNF- } \alpha \text {-driven NETosis. }\end{array}$ & UC (in vivo) \\
\hline Zheng et al. [119] & PF-1355 & MPO & Inhibition of MPO & $\begin{array}{l}\text { Decreased neutrophil } \\
\text { recruitment and NETosis. }\end{array}$ & In vitro \\
\hline \multirow[t]{2}{*}{ Parker et al. [120] } & $\begin{array}{l}\text { ABAH } \\
\text { (4-aminobenzoic } \\
\text { acid hydrazide) }\end{array}$ & \multirow[t]{2}{*}{ MPO } & \multirow[t]{2}{*}{ Inhibition of MPO } & \multirow{2}{*}{$\begin{array}{l}\text { Reduced PMA-induced NET } \\
\text { formation. }\end{array}$} & \multirow[t]{2}{*}{ In vitro } \\
\hline & $\begin{array}{l}\text { TX1 (3-isobutyl-2- } \\
\text { thioxo-7H-purine- } \\
\text { 6-one) }\end{array}$ & & & & \\
\hline Smith et al. [127] & Chloroquine & & & $\begin{array}{l}\text { Reduced LPS-induced NET } \\
\text { formation. }\end{array}$ & In vitro \\
\hline Fuchs et al. [128] & Heparin & Histones & $\begin{array}{l}\text { Remove histones from } \\
\text { NETs and destabilize } \\
\text { NETs }\end{array}$ & Reduced NET formation. & In vitro \\
\hline \multirow{2}{*}{$\begin{array}{l}\text { Manda-Handzlik } \\
\text { et al. [129] }\end{array}$} & Apocynin and DPI & NADPH-oxidase & $\begin{array}{l}\text { Inhibit } \\
\text { NADPH-oxidase } \\
\text { activity }\end{array}$ & $\begin{array}{l}\text { Reduced S-nitroso-N-acetyl- } \\
\text { D,L-penicillamine } \\
\text { (SNAP)-induced } \\
\text { NET formation. }\end{array}$ & \multirow[t]{2}{*}{ In vitro } \\
\hline & $\begin{array}{l}\mathrm{N} \text {-acetylcysteine } \\
\text { (NAC) }\end{array}$ & ROS scavenger & $\begin{array}{l}\text { Interfere with the levels } \\
\text { of hydrogen peroxide } \\
\text { and hydroxyl radical }\end{array}$ & $\begin{array}{l}\text { Inhibited NO-dependent } \\
\text { NETosis }\end{array}$ & \\
\hline \multirow{3}{*}{ Li et al. [117] } & SMT & $\begin{array}{l}\text { Inducible NO } \\
\text { synthase (iNOS) }\end{array}$ & \multirow{3}{*}{ Block NO synthesis } & \multirow{3}{*}{$\begin{array}{l}\text { Inhibited NO-mediated NET } \\
\text { formation }\end{array}$} & \multirow{3}{*}{ In vitro } \\
\hline & L-NAME & $\begin{array}{l}\text { Endothelial NO } \\
\text { synthase (eNOS) }\end{array}$ & & & \\
\hline & L-NMMA & Total NOS & & & \\
\hline Wang et al. [34] & $\begin{array}{l}\text { Metformin } \\
\text { (antidiabetic) }\end{array}$ & & $\begin{array}{l}\text { Inhibit mitochondrial } \\
\text { respiratory chain } \\
\text { complex I and } \\
\text { NADPH-oxidase } \\
\text { activity, thus decrease } \\
\text { ROS production }\end{array}$ & $\begin{array}{l}\text { Reduced PMA-induced NET } \\
\text { formation }\end{array}$ & In vitro \\
\hline $\begin{array}{l}\text { Menegazzo et al. } \\
\text { [124] }\end{array}$ & $\begin{array}{l}\text { Metformin } \\
\text { (antidiabetic) }\end{array}$ & & $\begin{array}{l}\text { Inhibit membrane } \\
\text { translocation of } \\
\text { PKC- } \beta \text { II and activation } \\
\text { of NADPH-oxidase }\end{array}$ & $\begin{array}{l}\text { Reduced NET components } \\
\text { elastase, proteinase-3, } \\
\text { histones, and double strand } \\
\text { DNA in the plasma of } \\
\text { pre-diabetes. }\end{array}$ & $\begin{array}{l}\text { Pre-diabetes } \\
\text { (in vivo and } \\
\text { in vitro) }\end{array}$ \\
\hline Zhang et al. [125] & $\begin{array}{l}\text { Hydroxychloroquine } \\
\text { (autophagy } \\
\text { inhibitor) }\end{array}$ & & $\begin{array}{l}\text { Inhibit PAD4 and Rac2 } \\
\text { expressions by } \\
\text { blocking TLR9 }\end{array}$ & $\begin{array}{l}\text { Reduced hepatic } \\
\text { ischemia/reperfusion (I/R) } \\
\text { injury by inhibiting NET } \\
\text { formation. }\end{array}$ & $\begin{array}{l}\text { Hepatic I/R injury } \\
\text { (in vivo and } \\
\text { in vitro) }\end{array}$ \\
\hline
\end{tabular}


Table 2. Cont.

\begin{tabular}{|c|c|c|c|c|c|}
\hline Studies & $\begin{array}{l}\text { Therapeutic } \\
\text { Agents }\end{array}$ & Targets & Mechanism of Action & Major Findings & Disease/Model \\
\hline $\begin{array}{l}\text { Phase II clinical } \\
\text { trial (NCT02462265, } \\
\text { https:// } \\
\text { clinicaltrials.gov) } \\
\text { Accessed on } 30 \\
\text { June } 2021\end{array}$ & $\begin{array}{l}\text { Oshadi D (DNase) } \\
\text { and Oshadi R } \\
\text { (RNase) }\end{array}$ & DNA and RNA & & $\begin{array}{l}\text { Showed antitumor activity } \\
\text { and a good safety profile in } \\
\text { leukemia patients. }\end{array}$ & $\begin{array}{l}\text { Acute myeloid } \\
\text { leukemia or acute } \\
\text { lymphoid leukemia }\end{array}$ \\
\hline
\end{tabular}

\section{Conclusions}

Despite significant preclinical and clinical research on CRC, mortality remains high when cancer progresses to multiple organs. This could be due to poor understanding of pathological mechanism of CRC in the context of inflammation and NET formation. Inflammation plays a profound role throughout the whole process of carcinogenesis staring from initiation of primary tumor to metastasis. Moreover, neutrophils and neutrophil-released products have been implicated in various types of cancer progression and metastasis. Although some studies showed anti-tumor roles of neutrophils, higher levels of neutrophils numbers in primary cancer and pre-metastatic organs were shown to associate with cancer progression and metastasis. The formation of NETs is an indispensable mechanism of host response where neutrophils kill and trap pathogens. However, in various cancer types, NETs were found to promote cancer cells growth and metastasis by trapping circulating cancer cells in distant inflamed organs. Although, a small number of studies investigated possible roles of NETs in CRC, increasingly a robust body of evidence indicated that NETs might play a significant role in the pathophysiology of colon cancer. In recent times, several experimental studies targeting NETs and NET-associated proteins showed promising results in mitigating disease progression and metastasis. Thus, it could be suggested that in conjunction with surgery and adjuvant chemotherapy, new treatment strategies in order to prevent NET-mediated CRC progression and metastasis would be a promising approach in the clinical settings. It should be noted that recombinant human DNase I has been used for patients with cystic fibrosis and systemic lupus erythematosus, respectively and appears to be safe and effective. Therefore, targeting NETs or NET formation could provide a promising strategy to inhibit both progression and metastasis of CRC.

Author Contributions: Extensive literature search and manuscript drafting, U.K. and S.C.; critical revision of the work and final version approval, M.M.B., K.M.D.I. and H.T.; conceptualization, drafting, figure preparation, critical revision of manuscript, and final version approval, M.R. All authors contributed to the article and approved the submitted version. All authors have read and agreed to the published version of the manuscript.

Funding: Cancerfonden (19 $0428 \mathrm{Pj}$ ).

Acknowledgments: Graphical images were prepared using digital contents from SERVIER MEDICAL ART (https:/ / smart.servier.com) covered by CC BY license.

Conflicts of Interest: The authors declare no conflict of interest.

\section{References}

1. Bray, F.; Ferlay, J.; Soerjomataram, I.; Siegel, R.L.; Torre, L.A.; Jemal, A. Global cancer statistics 2018: GLOBOCAN estimates of incidence and mortality worldwide for 36 cancers in 185 countries. CA Cancer J. Clin. 2018, 68, 394-424. [CrossRef]

2. Douaiher, J.; Ravipati, A.; Grams, B.; Chowdhury, S.; Alatise, O.; Are, C. Colorectal cancer-global burden, trends, and geographical variations. J. Surg. Oncol. 2017, 115, 619-630. [CrossRef]

3. Simon, K. Colorectal cancer development and advances in screening. Clin. Interv. Aging 2016, 11, 967-976.

4. Filip, S.; Vymetalkova, V.; Petera, J.; Vodickova, L.; Kubecek, O.; John, S.; Cecka, F.; Krupova, M.; Manethova, M.; Cervena, K. Distant Metastasis in Colorectal Cancer Patients-Do We Have New Predicting Clinicopathological and Molecular Biomarkers? A Comprehensive Review. Int. J. Mol. Sci. 2020, 21, 5255. [CrossRef] 
5. Schmoll, H.J.; Van Cutsem, E.; Stein, A.; Valentini, V.; Glimelius, B.; Haustermans, K.; Nordlinger, B.; van de Velde, C.J.; Balmana, J.; Regula, J. ESMO Consensus Guidelines for management of patients with colon and rectal cancer. a personalized approach to clinical decision making. Ann. Oncol. 2012, 23, 2479-2516. [CrossRef] [PubMed]

6. Bockelman, C.; Engelmann, B.E.; Kaprio, T.; Hansen, T.F.; Glimelius, B. Risk of recurrence in patients with colon cancer stage II and III: A systematic review and meta-analysis of recent literature. Acta Oncol. 2015, 54, 5-16. [CrossRef] [PubMed]

7. Holch, J.W.; Demmer, M.; Lamersdorf, C.; Michl, M.; Schulz, C.; von Einem, J.C.; Modest, D.P.; Heinemann, V. Pattern and Dynamics of Distant Metastases in Metastatic Colorectal Cancer. Visc. Med. 2017, 33, 70-75. [CrossRef] [PubMed]

8. Paschos, K.A.; Canovas, D.; Bird, N.C. The role of cell adhesion molecules in the progression of colorectal cancer and the development of liver metastasis. Cell Signal 2009, 21, 665-674. [CrossRef] [PubMed]

9. Mantovani, A.; Savino, B.; Locati, M.; Zammataro, L.; Allavena, P.; Bonecchi, R. The chemokine system in cancer biology and therapy. Cytokine Growth Factor Rev. 2010, 21, 27-39. [CrossRef]

10. Kawada, K.; Hosogi, H.; Sonoshita, M.; Sakashita, H.; Manabe, T.; Shimahara, Y.; Sakai, Y.; Takabayashi, A.; Oshima, M.; Taketo, M.M. Chemokine receptor CXCR3 promotes colon cancer metastasis to lymph nodes. Oncogene 2007, 26, 4679-4688. [CrossRef]

11. Nagai, N.; Kudo, Y.; Aki, D.; Nakagawa, H.; Taniguchi, K. Immunomodulation by Inflammation during Liver and Gastrointestinal Tumorigenesis and Aging. Int. J. Mol. Sci. 2021, 22, 2238. [CrossRef]

12. Okada, F. Inflammation-related carcinogenesis: Current findings in epidemiological trends, causes and mechanisms. Yonago Acta Med. 2014, 57, 65-72.

13. Vendramini-Costa, D.B.; Carvalho, J.E. Molecular link mechanisms between inflammation and cancer. Curr. Pharm Des. 2012, 18, 3831-3852. [CrossRef]

14. Kowanetz, M.; Wu, X.; Lee, J.; Tan, M.; Hagenbeek, T.; Qu, X.; Yu, L.; Ross, J.; Korsisaari, N.; Cao, T. Granulocyte-colony stimulating factor promotes lung metastasis through mobilization of Ly6G+Ly6C+ granulocytes. Proc. Natl. Acad. Sci. USA 2010, 107, 21248-21255. [CrossRef] [PubMed]

15. Xing, X.; Bai, Y.; Song, J. The Heterogeneity of Neutrophil Recruitment in the Tumor Microenvironment and the Formation of Premetastatic Niches. J. Immunol. Res. 2021, 2021, 6687474. [CrossRef] [PubMed]

16. Kaplan, M.J.; Radic, M. Neutrophil extracellular traps: Double-edged swords of innate immunity. J. Immunol. 2012, 189, 2689-2695. [CrossRef] [PubMed]

17. Arpinati, L.; Shaul, M.E.; Kaisar-Iluz, N.; Mali, S.; Mahroum, S.; Fridlender, Z.G. NETosis in cancer: A critical analysis of the impact of cancer on neutrophil extracellular trap (NET) release in lung cancer patients vs. mice. Cancer Immunol. Immunother 2020, 69, 199-213. [CrossRef]

18. Erpenbeck, L.; Schon, M.P. Neutrophil extracellular traps: Protagonists of cancer progression? Oncogene 2017, 36, 2483-2490. [CrossRef] [PubMed]

19. Jung, H.S.; Gu, J.; Kim, J.E.; Nam, Y.; Song, J.W.; Kim, H.K. Cancer cell-induced neutrophil extracellular traps promote both hypercoagulability and cancer progression. PLOS ONE 2019, 14, e0216055. [CrossRef] [PubMed]

20. Homa-Mlak, I.; Majdan, A.; Mlak, R.; Malecka-Massalska, T. Metastatic potential of NET in neoplastic disease. Postepy Hig. Med. Dosw. 2016, 70, 887-895. [CrossRef]

21. Masucci, M.T.; Minopoli, M.; Del Vecchio, S.; Carriero, M.V. The Emerging Role of Neutrophil Extracellular Traps (NETs) in Tumor Progression and Metastasis. Front Immunol. 2020, 11, 1749. [CrossRef]

22. Cools-Lartigue, J.; Spicer, J.; McDonald, B.; Gowing, S.; Chow, S.; Giannias, B.; Bourdeau, F.; Kubes, P.; Ferri, L. Neutrophil extracellular traps sequester circulating tumor cells and promote metastasis. J. Clin. Investig. 2013, 123, 3446-3458. [CrossRef] [PubMed]

23. Demers, M.; Krause, D.S.; Schatzberg, D.; Martinod, K.; Voorhees, J.R.; Fuchs, T.A.; Scadden, D.T.; Wagner, D.D. Cancers predispose neutrophils to release extracellular DNA traps that contribute to cancer-associated thrombosis. Proc. Natl. Acad. Sci. USA 2012, 109, 13076-13081. [CrossRef] [PubMed]

24. Onuma, A.E.; Zhang, H.; Gil, L.; Huang, H.; Tsung, A. Surgical Stress Promotes Tumor Progression: A Focus on the Impact of the Immune Response. J. Clin. Med. 2020, 9, 4096. [CrossRef]

25. Tohme, S.; Yazdani, H.O.; Al-Khafaji, A.B.; Chidi, A.P.; Loughran, P.; Mowen, K.; Wang, Y.; Simmons, R.L.; Huang, H.; Tsung, A. Neutrophil Extracellular Traps Promote the Development and Progression of Liver Metastases after Surgical Stress. Cancer Res. 2016, 76, 1367-1380. [CrossRef] [PubMed]

26. Arelaki, S.; Arampatzioglou, A.; Kambas, K.; Papagoras, C.; Miltiades, P.; Angelidou, I.; Mitsios, A.; Kotsianidis, I.; Skendros, P.; Sivridis, E. Gradient Infiltration of Neutrophil Extracellular Traps in Colon Cancer and Evidence for Their Involvement in Tumour Growth. PLoS ONE 2016, 11, e0154484. [CrossRef]

27. Jorch, S.K.; Kubes, P. An emerging role for neutrophil extracellular traps in noninfectious disease. Nat. Med. 2017, 23, 279-287. [CrossRef]

28. Ravindran, M.; Khan, M.A.; Palaniyar, N. Neutrophil Extracellular Trap Formation: Physiology, Pathology, and Pharmacology. Biomolecules 2019, 9, 365. [CrossRef]

29. Kobayashi, S.D.; DeLeo, F.R. Role of neutrophils in innate immunity: A systems biology-level approach. Wiley Interdiscip Rev. Syst. Biol. Med. 2009, 1, 309-333. [CrossRef] 
30. Wang, Y.; Li, M.; Stadler, S.; Correll, S.; Li, P.; Wang, D.; Hayama, R.; Leonelli, L.; Han, H.; Grigoryev, S.A. Histone hypercitrullination mediates chromatin decondensation and neutrophil extracellular trap formation. J. Cell Biol. 2009, 184, 205-213. [CrossRef]

31. Metzler, K.D.; Goosmann, C.; Lubojemska, A.; Zychlinsky, A.; Papayannopoulos, V. A myeloperoxidase-containing complex regulates neutrophil elastase release and actin dynamics during NETosis. Cell Rep. 2014, 8, 883-896. [CrossRef]

32. Fuchs, T.A.; Abed, U.; Goosmann, C.; Hurwitz, R.; Schulze, I.; Wahn, V.; Weinrauch, Y.; Brinkmann, V.; Zychlinsky, A. Novel cell death program leads to neutrophil extracellular traps. J. Cell Biol. 2007, 176, 231-241. [CrossRef]

33. Yousefi, S.; Mihalache, C.; Kozlowski, E.; Schmid, I.; Simon, H.U. Viable neutrophils release mitochondrial DNA to form neutrophil extracellular traps. Cell Death Differ 2009, 16, 1438-1444. [CrossRef] [PubMed]

34. Wang, H.; Li, T.; Chen, S.; Gu, Y.; Ye, S. Neutrophil Extracellular Trap Mitochondrial DNA and Its Autoantibody in Systemic Lupus Erythematosus and a Proof-of-Concept Trial of Metformin. Arthritis Rheumatol. 2015, 67, 3190-3200. [CrossRef] [PubMed]

35. Honda, M.; Kubes, P. Neutrophils and neutrophil extracellular traps in the liver and gastrointestinal system. Nat. Rev. Gastroenterol. Hepatol. 2018, 15, 206-221. [CrossRef] [PubMed]

36. Pilsczek, F.H.; Salina, D.; Poon, K.K.; Fahey, C.; Yipp, B.G.; Sibley, C.D.; Robbins, S.M.; Green, F.H.; Surette, M.G.; Sugai, M. A novel mechanism of rapid nuclear neutrophil extracellular trap formation in response to Staphylococcus aureus. J. Immunol. 2010, 185, 7413-7425. [CrossRef]

37. Yipp, B.G.; Petri, B.; Salina, D.; Jenne, C.N.; Scott, B.N.; Zbytnuik, L.D.; Pittman, K.; Asaduzzaman, M.; Wu, K.; Meijndert, H.C. Infection-induced NETosis is a dynamic process involving neutrophil multitasking in vivo. Nat. Med. 2012, 18, 1386-1393. [CrossRef] [PubMed]

38. Rochael, N.C.; Guimaraes-Costa, A.B.; Nascimento, M.T.; DeSouza-Vieira, T.S.; Oliveira, M.P.; Garcia e Souza, L.F.; Oliveira, M.F.; Saraiva, E.M. Classical ROS-dependent and early/rapid ROS-independent release of Neutrophil Extracellular Traps triggered by Leishmania parasites. Sci. Rep. 2015, 5, 18302. [CrossRef]

39. Maronek, M.; Gromova, B.; Liptak, R.; Konecna, B.; Pastorek, M.; Cechova, B.; Harsanyova, M.; Budis, J.; Smolak, D.; Radvanszky, J. Extracellular DNA Correlates with Intestinal Inflammation in Chemically Induced Colitis in Mice. Cells 2021, 10, 81. [CrossRef]

40. Lin, E.Y.; Lai, H.J.; Cheng, Y.K.; Leong, K.Q.; Cheng, L.C.; Chou, Y.C.; Peng, Y.C.; Hsu, Y.H.; Chiang, H.S. Neutrophil Extracellular Traps Impair Intestinal Barrier Function during Experimental Colitis. Biomedicines 2020, 8, 275. [CrossRef]

41. Gottlieb, Y.; Elhasid, R.; Berger-Achituv, S.; Brazowski, E.; Yerushalmy-Feler, A.; Cohen, S. Neutrophil extracellular traps in pediatric inflammatory bowel disease. Pathol. Int. 2018, 68, 517-523. [CrossRef]

42. Wan, J.; Ren, Y.; Yang, X.; Li, X.; Xia, L.; Lu, N. The Role of Neutrophils and Neutrophil Extracellular Traps in Acute Pancreatitis. Front. Cell Dev. Biol. 2020, 8, 565758. [CrossRef]

43. Murthy, P.; Singhi, A.D.; Ross, M.A.; Loughran, P.; Paragomi, P.; Papachristou, G.I.; Whitcomb, D.C.; Zureikat, A.H.; Lotze, M.T.; Zeh Iii, H.J. Enhanced Neutrophil Extracellular Trap Formation in Acute Pancreatitis Contributes to Disease Severity and Is Reduced by Chloroquine. Front. Immunol. 2019, 10, 28. [CrossRef]

44. Merza, M.; Hartman, H.; Rahman, M.; Hwaiz, R.; Zhang, E.; Renstrom, E.; Luo, L.; Morgelin, M.; Regner, S.; Thorlacius, H. Neutrophil Extracellular Traps Induce Trypsin Activation, Inflammation, and Tissue Damage in Mice With Severe Acute Pancreatitis. Gastroenterology 2015, 149, 1920-1931.e8. [CrossRef] [PubMed]

45. Angelidou, I.; Chrysanthopoulou, A.; Mitsios, A.; Arelaki, S.; Arampatzioglou, A.; Kambas, K.; Ritis, D.; Tsironidou, V.; Moschos, I.; Dalla, V. REDD1/Autophagy Pathway Is Associated with Neutrophil-Driven IL-1beta Inflammatory Response in Active Ulcerative Colitis. J. Immunol. 2018, 200, 3950-3961. [CrossRef] [PubMed]

46. Dinallo, V.; Marafini, I.; Di Fusco, D.; Laudisi, F.; Franze, E.; Di Grazia, A.; Figliuzzi, M.M.; Caprioli, F.; Stolfi, C.; Monteleone, I. Neutrophil Extracellular Traps Sustain Inflammatory Signals in Ulcerative Colitis. J. Crohns Colitis 2019, 13, 772-784. [CrossRef] [PubMed]

47. Li, T.; Wang, C.; Liu, Y.; Li, B.; Zhang, W.; Wang, L.; Yu, M.; Zhao, X.; Du, J.; Zhang, J. Neutrophil Extracellular Traps Induce Intestinal Damage and Thrombotic Tendency in Inflammatory Bowel Disease. J. Crohns Colitis 2020, 14, 240-253. [CrossRef]

48. Ginzel, M.; Feng, X.; Kuebler, J.F.; Klemann, C.; Yu, Y.; von Wasielewski, R.; Park, J.K.; Hornef, M.W.; Vieten, G.; Ure, B.M. Dextran sodium sulfate (DSS) induces necrotizing enterocolitis-like lesions in neonatal mice. PLoS ONE 2017, 12, e0182732. [CrossRef]

49. Vincent, D.; Klinke, M.; Eschenburg, G.; Trochimiuk, M.; Appl, B.; Tiemann, B.; Bergholz, R.; Reinshagen, K.; Boettcher, M. NEC is likely a NETs dependent process and markers of NETosis are predictive of NEC in mice and humans. Sci. Rep. 2018, 8, 12612. [CrossRef]

50. Kim, T.; de Oliveira Silva Lautenschlager, S.; Ma, Q.; Eller, K.; Pollheimer, M.J.; Lazarin-Bidoia, D.; Nakamura, C.V.; Anders, H.J.; Steiger, S. Drug Crystal-Related Gastrointestinal Complications Involve Crystal-Induced Release of Neutrophil and Monocyte Extracellular Traps. Cells 2020, 9, 2481. [CrossRef]

51. Desai, J.; Foresto-Neto, O.; Honarpisheh, M.; Steiger, S.; Nakazawa, D.; Popper, B.; Buhl, E.M.; Boor, P.; Mulay, S.R.; Anders, H.J Particles of different sizes and shapes induce neutrophil necroptosis followed by the release of neutrophil extracellular trap-like chromatin. Sci. Rep. 2017, 7, 15003. [CrossRef] [PubMed]

52. Sarhan, M.; Land, W.G.; Tonnus, W.; Hugo, C.P.; Linkermann, A. Origin and Consequences of Necroinflammation. Physiol. Rev. 2018, 98, 727-780. [CrossRef]

53. Zhou, G.; Song, Y.; Yang, W.; Guo, Y.; Fang, L.; Chen, Y.; Liu, Z. ASCA, ANCA, ALCA and Many More: Are They Useful in the Diagnosis of Inflammatory Bowel Disease? Dig. Dis. 2016, 34, 90-97. [CrossRef] [PubMed] 
54. Jarrot, P.A.; Kaplanski, G. Pathogenesis of ANCA-associated vasculitis: An update. Autoimmun. Rev. 2016, 15, 704-713. [CrossRef] [PubMed]

55. Kessenbrock, K.; Krumbholz, M.; Schonermarck, U.; Back, W.; Gross, W.L.; Werb, Z.; Grone, H.J.; Brinkmann, V.; Jenne, D.E. Netting neutrophils in autoimmune small-vessel vasculitis. Nat. Med. 2009, 15, 623-625. [CrossRef]

56. Sangaletti, S.; Tripodo, C.; Chiodoni, C.; Guarnotta, C.; Cappetti, B.; Casalini, P.; Piconese, S.; Parenza, M.; Guiducci, C.; Vitali, C. Neutrophil extracellular traps mediate transfer of cytoplasmic neutrophil antigens to myeloid dendritic cells toward ANCA induction and associated autoimmunity. Blood 2012, 120, 3007-3018. [CrossRef]

57. Mahler, M.; Bogdanos, D.P.; Pavlidis, P.; Fritzler, M.J.; Csernok, E.; Damoiseaux, J.; Bentow, C.; Shums, Z.; Forbes, A.; Norman, G.L. PR3-ANCA: A promising biomarker for ulcerative colitis with extensive disease. Clin. Chim. Acta 2013, 424, 267-273. [CrossRef] [PubMed]

58. Drury, B.; Hardisty, G.; Gray, R.D.; Ho, G.T. Neutrophil Extracellular Traps in Inflammatory Bowel Disease: Pathogenic Mechanisms and Clinical Translation. Cell Mol. Gastroenterol. Hepatol. 2021, 12, 321-333. [CrossRef]

59. Gutierrez, A.; Frances, R.; Amoros, A.; Zapater, P.; Garmendia, M.; Ndongo, M.; Cano, R.; Jover, R.; Such, J.; Perez-Mateo, M. Cytokine association with bacterial DNA in serum of patients with inflammatory bowel disease. Inflamm. Bowel Dis. 2009, 15, 508-514. [CrossRef] [PubMed]

60. Gutierrez, A.; Zapater, P.; Juanola, O.; Sempere, L.; Garcia, M.; Laveda, R.; Martinez, A.; Scharl, M.; Gonzalez-Navajas, J.M.; Such, J. Gut Bacterial DNA Translocation is an Independent Risk Factor of Flare at Short Term in Patients With Crohn's Disease. Am. J. Gastroenterol. 2016, 111, 529-540. [CrossRef] [PubMed]

61. Vrakas, S.; Mountzouris, K.C.; Michalopoulos, G.; Karamanolis, G.; Papatheodoridis, G.; Tzathas, C.; Gazouli, M. Intestinal Bacteria Composition and Translocation of Bacteria in Inflammatory Bowel Disease. PLoS ONE 2017, 12, e0170034. [CrossRef]

62. Oklu, R.; Sheth, R.A.; Wong, K.H.K.; Jahromi, A.H.; Albadawi, H. Neutrophil extracellular traps are increased in cancer patients but does not associate with venous thrombosis. Cardiovasc. Diagn Ther. 2017, 7 (Suppl. 3), S140-S149. [CrossRef] [PubMed]

63. Li, Y.; Yang, Y.; Gan, T.; Zhou, J.; Hu, F.; Hao, N.; Yuan, B.; Chen, Y.; Zhang, M. Extracellular RNAs from lung cancer cells activate epithelial cells and induce neutrophil extracellular traps. Int. J. Oncol. 2019, 55, 69-80. [CrossRef] [PubMed]

64. Yang, L.; Liu, Q.; Zhang, X.; Liu, X.; Zhou, B.; Chen, J.; Huang, D.; Li, J.; Li, H.; Chen, F. DNA of neutrophil extracellular traps promotes cancer metastasis via CCDC25. Nature 2020, 583, 133-138. [CrossRef] [PubMed]

65. Park, J.; Wysocki, R.W.; Amoozgar, Z.; Maiorino, L.; Fein, M.R.; Jorns, J.; Schott, A.F.; Kinugasa-Katayama, Y.; Lee, Y.; Won, N.H. Cancer cells induce metastasis-supporting neutrophil extracellular DNA traps. Sci. Transl. Med. 2016, 8, 361ra138. [CrossRef] [PubMed]

66. Albrengues, J.; Shields, M.A.; Ng, D.; Park, C.G.; Ambrico, A.; Poindexter, M.E.; Upadhyay, P.; Uyeminami, D.L.; Pommier, A.; Kuttner, V. Neutrophil extracellular traps produced during inflammation awaken dormant cancer cells in mice. Science 2018, 361, eaao4227. [CrossRef]

67. Millrud, C.R.; Kagedal, A.; Kumlien Georen, S.; Winqvist, O.; Uddman, R.; Razavi, R.; Munck-Wikland, E.; Cardell, L.O. NETproducing CD16(high) CD62L(dim) neutrophils migrate to tumor sites and predict improved survival in patients with HNSCC. Int. J. Cancer 2017, 140, 2557-2567. [CrossRef]

68. Demers, M.; Wong, S.L.; Martinod, K.; Gallant, M.; Cabral, J.E.; Wang, Y.; Wagner, D.D. Priming of neutrophils toward NETosis promotes tumor growth. Oncoimmunology 2016, 5, e1134073. [CrossRef]

69. Zhang, Y.; Hu, Y.; Ma, C.; Sun, H.; Wei, X.; Li, M.; Wei, W.; Zhang, F.; Yang, F.; Wang, H. Diagnostic, Therapeutic Predictive, and Prognostic Value of Neutrophil Extracellular Traps in Patients With Gastric Adenocarcinoma. Front. Oncol. 2020, 10, 1036. [CrossRef]

70. Kanamaru, R.; Ohzawa, H.; Miyato, H.; Matsumoto, S.; Haruta, H.; Kurashina, K.; Saito, S.; Hosoya, Y.; Yamaguchi, H.; Yamashita, $\mathrm{H}$. Low density neutrophils (LDN) in postoperative abdominal cavity assist the peritoneal recurrence through the production of neutrophil extracellular traps (NETs). Sci. Rep. 2018, 8, 632. [CrossRef]

71. Saini, K.S.; Tagliamento, M.; Lambertini, M.; McNally, R.; Romano, M.; Leone, M.; Curigliano, G.; de Azambuja, E. Mortality in patients with cancer and coronavirus disease 2019: A systematic review and pooled analysis of 52 studies. Eur. J. Cancer 2020, 139, 43-50. [CrossRef]

72. Barnes, B.J.; Adrover, J.M.; Baxter-Stoltzfus, A.; Borczuk, A.; Cools-Lartigue, J.; Crawford, J.M.; Dassler-Plenker, J.; Guerci, P.; Huynh, C.; Knight, J.S. Targeting potential drivers of COVID-19: Neutrophil extracellular traps. J. Exp. Med. 2020, 217, e20200652. [CrossRef] [PubMed]

73. Middleton, E.A.; He, X.Y.; Denorme, F.; Campbell, R.A.; Ng, D.; Salvatore, S.P.; Mostyka, M.; Baxter-Stoltzfus, A.; Borczuk, A.C.; Loda, M. Neutrophil extracellular traps contribute to immunothrombosis in COVID-19 acute respiratory distress syndrome. Blood 2020, 136, 1169-1179. [CrossRef] [PubMed]

74. Wang, B.; Huang, Y. Which type of cancer patients are more susceptible to the SARS-COX-2: Evidence from a meta-analysis and bioinformatics analysis. Crit. Rev. Oncol. Hematol. 2020, 153, 103032. [CrossRef] [PubMed]

75. He, C.; Hua, X.; Sun, S.; Li, S.; Wang, J.; Huang, X. Integrated Bioinformatic Analysis of SARS-CoV-2 Infection Related Genes ACE2, BSG and TMPRSS2 in Aerodigestive Cancers. J. Inflamm. Res. 2021, 14, 791-802. [CrossRef]

76. Tutuncuoglu, B.; Cakir, M.; Batra, J.; Bouhaddou, M.; Eckhardt, M.; Gordon, D.E.; Krogan, N.J. The Landscape of Human Cancer Proteins Targeted by SARS-CoV-2. Cancer Discov. 2020, 10, 916-921. [CrossRef] [PubMed] 
77. Muz, B.; de la Puente, P.; Azab, F.; Azab, A.K. The role of hypoxia in cancer progression, angiogenesis, metastasis, and resistance to therapy. Hypoxia 2015, 3, 83-92. [CrossRef]

78. Francescangeli, F.; De Angelis, M.L.; Zeuner, A. COVID-19: A potential driver of immune-mediated breast cancer recurrence? Breast Cancer Res. 2020, 22, 117. [CrossRef]

79. Fluegen, G.; Avivar-Valderas, A.; Wang, Y.; Padgen, M.R.; Williams, J.K.; Nobre, A.R.; Calvo, V.; Cheung, J.F.; Bravo-Cordero, J.J.; Entenberg, D. Phenotypic heterogeneity of disseminated tumour cells is preset by primary tumour hypoxic microenvironments. Nat. Cell Biol. 2017, 19, 120-132. [CrossRef]

80. Vabret, N.; Britton, G.J.; Gruber, C.; Hegde, S.; Kim, J.; Kuksin, M.; Levantovsky, R.; Malle, L.; Moreira, A.; Park, M.D. Immunology of COVID-19: Current State of the Science. Immunity 2020, 52, 910-941. [CrossRef]

81. Richardson, J.J.R.; Hendrickse, C.; Gao-Smith, F.; Thickett, D.R. Neutrophil Extracellular Trap Production in Patients with Colorectal Cancer In Vitro. Int. J. Inflam. 2017, 2017, 4915062. [CrossRef] [PubMed]

82. Shang, A.; Gu, C.; Zhou, C.; Yang, Y.; Chen, C.; Zeng, B.; Wu, J.; Lu, W.; Wang, W.; Sun, Z. Exosomal KRAS mutation promotes the formation of tumor-associated neutrophil extracellular traps and causes deterioration of colorectal cancer by inducing IL-8 expression. Cell Commun. Signal 2020, 18, 52. [CrossRef] [PubMed]

83. Hellinger, M.D.; Santiago, C.A. Reoperation for recurrent colorectal cancer. Clin. Colon Rectal. Surg. 2006, 19, 228-236. [CrossRef]

84. Carroll, G.M.; Burns, G.L.; Petit, J.A.; Walker, M.M.; Mathe, A.; Smith, S.R.; Keely, S.; Pockney, P.G. Does postoperative inflammation or sepsis generate neutrophil extracellular traps that influence colorectal cancer progression? A systematic review. Surg. Open Sci. 2020, 2, 57-69. [CrossRef]

85. Arelaki, S.; Arampatzioglou, A.; Kambas, K.; Sivridis, E.; Giatromanolaki, A.; Ritis, K. Mast cells co-expressing CD68 and inorganic polyphosphate are linked with colorectal cancer. PLoS ONE 2018, 13, e0193089. [CrossRef] [PubMed]

86. Bolt, M.J.; Mailloux, R.J.; Rasenick, M.M.; Wali, R.K.; Skarosi, S.; Bissonnette, M.; Brasitus, T.A.; Sitrin, M.D. Expression of $\mathrm{G}$ protein alpha subunits in normal rat colon and in azoxymethane-induced colonic neoplasms. Gastroenterology 1998, 115, 1494-1503. [CrossRef]

87. Najumudeen, A.K.; Ceteci, F.; Fey, S.K.; Hamm, G.; Steven, R.T.; Hall, H.; Nikula, C.J.; Dexter, A.; Murta, T.; Race, A.M. The amino acid transporter SLC7A5 is required for efficient growth of KRAS-mutant colorectal cancer. Nat. Genet. 2021, 53, 16-26. [CrossRef] [PubMed]

88. Sunaga, N.; Imai, H.; Shimizu, K.; Shames, D.S.; Kakegawa, S.; Girard, L.; Sato, M.; Kaira, K.; Ishizuka, T.; Gazdar, A.F. Oncogenic KRAS-induced interleukin-8 overexpression promotes cell growth and migration and contributes to aggressive phenotypes of non-small cell lung cancer. Int. J. Cancer 2012, 130, 1733-1744. [CrossRef]

89. Walther, A.; Johnstone, E.; Swanton, C.; Midgley, R.; Tomlinson, I.; Kerr, D. Genetic prognostic and predictive markers in colorectal cancer. Nat. Rev. Cancer 2009, 9, 489-499. [CrossRef]

90. Teijeira, A.; Garasa, S.; Ochoa, M.C.; Villalba, M.; Olivera, I.; Cirella, A.; Eguren-Santamaria, I.; Berraondo, P.; Schalper, K.A.; de Andrea, C.E. IL8, Neutrophils, and NETs in a Collusion against Cancer Immunity and Immunotherapy. Clin. Cancer Res. 2020. [CrossRef]

91. Lee, Y.S.; Choi, I.; Ning, Y.; Kim, N.Y.; Khatchadourian, V.; Yang, D.; Chung, H.K.; Choi, D.; LaBonte, M.J.; Ladner, R.D. Interleukin-8 and its receptor CXCR2 in the tumour microenvironment promote colon cancer growth, progression and metastasis. Br. J. Cancer 2012, 106, 1833-1841. [CrossRef]

92. Alfaro, C.; Teijeira, A.; Onate, C.; Perez, G.; Sanmamed, M.F.; Andueza, M.P.; Alignani, D.; Labiano, S.; Azpilikueta, A.; RodriguezPaulete, A. Tumor-Produced Interleukin-8 Attracts Human Myeloid-Derived Suppressor Cells and Elicits Extrusion of Neutrophil Extracellular Traps (NETs). Clin. Cancer Res. 2016, 22, 3924-3936. [CrossRef] [PubMed]

93. Alfaro, C.; Sanmamed, M.F.; Rodriguez-Ruiz, M.E.; Teijeira, A.; Onate, C.; Gonzalez, A.; Ponz, M.; Schalper, K.A.; Perez-Gracia, J.L.; Melero, I. Interleukin-8 in cancer pathogenesis, treatment and follow-up. Cancer Treat Rev. 2017, 60, 24-31. [CrossRef] [PubMed]

94. Yang, L.; Liu, L.; Zhang, R.; Hong, J.; Wang, Y.; Wang, J.; Zuo, J.; Zhang, J.; Chen, J.; Hao, H. IL-8 mediates a positive loop connecting increased neutrophil extracellular traps (NETs) and colorectal cancer liver metastasis. J. Cancer 2020, 11, 4384-4396. [CrossRef]

95. Nie, M.; Yang, L.; Bi, X.; Wang, Y.; Sun, P.; Yang, H.; Liu, P.; Li, Z.; Xia, Y.; Jiang, W. Neutrophil Extracellular Traps Induced by IL8 Promote Diffuse Large B-cell Lymphoma Progression via the TLR9 Signaling. Clin. Cancer Res. 2019, 25, 1867-1879. [CrossRef] [PubMed]

96. Rayes, R.F.; Mouhanna, J.G.; Nicolau, I.; Bourdeau, F.; Giannias, B.; Rousseau, S.; Quail, D.; Walsh, L.; Sangwan, V.; Bertos, N. Primary tumors induce neutrophil extracellular traps with targetable metastasis promoting effects. JCI Insight 2019, 5, e128008. [CrossRef] [PubMed]

97. Mizuno, R.; Kawada, K.; Itatani, Y.; Ogawa, R.; Kiyasu, Y.; Sakai, Y. The Role of Tumor-Associated Neutrophils in Colorectal Cancer. Int. J. Mol. Sci. 2019, 20, 529. [CrossRef]

98. Yazdani, H.O.; Roy, E.; Comerci, A.J.; van der Windt, D.J.; Zhang, H.; Huang, H.; Loughran, P.; Shiva, S.; Geller, D.A.; Bartlett, D.L. Neutrophil Extracellular Traps Drive Mitochondrial Homeostasis in Tumors to Augment Growth. Cancer Res. 2019, 79, 5626-5639. [CrossRef] [PubMed]

99. Oosterling, S.J.; van der Bij, G.J.; van Egmond, M.; van der Sijp, J.R. Surgical trauma and peritoneal recurrence of colorectal carcinoma. Eur. J. Surg. Oncol. 2005, 31, 29-37. [CrossRef] 
100. Lepsenyi, M.; Algethami, N.; Al-Haidari, A.A.; Algaber, A.; Syk, I.; Rahman, M.; Thorlacius, H. CXCL2-CXCR2 axis mediates alphaV integrin-dependent peritoneal metastasis of colon cancer cells. Clin. Exp. Metastasis 2021. [CrossRef]

101. Xia, Y.; He, J.; Zhang, H.; Wang, H.; Tetz, G.; Maguire, C.A.; Wang, Y.; Onuma, A.; Genkin, D.; Tetz, V. AAV-mediated gene transfer of DNase I in the liver of mice with colorectal cancer reduces liver metastasis and restores local innate and adaptive immune response. Mol. Oncol. 2020, 14, 2920-2935. [CrossRef]

102. Rayes, R.F.; Vourtzoumis, P.; Bou Rjeily, M.; Seth, R.; Bourdeau, F.; Giannias, B.; Berube, J.; Huang, Y.H.; Rousseau, S.; CamilleriBroet, S. Neutrophil Extracellular Trap-Associated CEACAM1 as a Putative Therapeutic Target to Prevent Metastatic Progression of Colon Carcinoma. J. Immunol. 2020, 204, 2285-2294. [CrossRef]

103. Richardson, J.J.R.; Hendrickse, C.; Gao-Smith, F.; Thickett, D.R. Characterization of systemic neutrophil function in patients undergoing colorectal cancer resection. J. Surg. Res. 2017, 220, 410-418.e1. [CrossRef] [PubMed]

104. Shah, P.L.; Scott, S.F.; Knight, R.A.; Marriott, C.; Ranasinha, C.; Hodson, M.E. In vivo effects of recombinant human DNase I on sputum in patients with cystic fibrosis. Thorax 1996, 51, 119-125. [CrossRef]

105. Klinke, M.; Vincent, D.; Trochimiuk, M.; Appl, B.; Tiemann, B.; Bergholz, R.; Reinshagen, K.; Boettcher, M. Degradation of Extracellular DNA Significantly Ameliorates Necrotizing Enterocolitis Severity in Mice. J. Surg. Res. 2019, 235, 513-520. [CrossRef] [PubMed]

106. Wen, F.; Shen, A.; Choi, A.; Gerner, E.W.; Shi, J. Extracellular DNA in pancreatic cancer promotes cell invasion and metastasis. Cancer Res. 2013, 73, 4256-4266. [CrossRef]

107. Yang, C.; Montgomery, M. Dornase alfa for cystic fibrosis. Cochrane Database Syst. Rev. 2021, 3, CD001127.

108. Kolaczkowska, E.; Jenne, C.N.; Surewaard, B.G.; Thanabalasuriar, A.; Lee, W.Y.; Sanz, M.J.; Mowen, K.; Opdenakker, G.; Kubes, P. Molecular mechanisms of NET formation and degradation revealed by intravital imaging in the liver vasculature. Nat. Commun. 2015, 6, 6673. [CrossRef]

109. Duranton, J.; Boudier, C.; Belorgey, D.; Mellet, P.; Bieth, J.G. DNA strongly impairs the inhibition of cathepsin G by alpha(1)antichymotrypsin and alpha(1)-proteinase inhibitor. J. Biol. Chem. 2000, 275, 3787-3792. [CrossRef]

110. Belorgey, D.; Bieth, J.G. Effect of polynucleotides on the inhibition of neutrophil elastase by mucus proteinase inhibitor and alpha 1-proteinase inhibitor. Biochemistry 1998, 37, 16416-16422. [CrossRef] [PubMed]

111. Saffarzadeh, M.; Juenemann, C.; Queisser, M.A.; Lochnit, G.; Barreto, G.; Galuska, S.P.; Lohmeyer, J.; Preissner, K.T. Neutrophil extracellular traps directly induce epithelial and endothelial cell death: A predominant role of histones. PLoS ONE 2012, 7, e32366. [CrossRef]

112. Khan, M.A.; Palaniyar, N. Transcriptional firing helps to drive NETosis. Sci. Rep. 2017, 7, 41749. [CrossRef]

113. Lood, C.; Blanco, L.P.; Purmalek, M.M.; Carmona-Rivera, C.; De Ravin, S.S.; Smith, C.K.; Malech, H.L.; Ledbetter, J.A.; Elkon, K.B.; Kaplan, M.J. Neutrophil extracellular traps enriched in oxidized mitochondrial DNA are interferogenic and contribute to lupus-like disease. Nat. Med. 2016, 22, 146-153. [CrossRef] [PubMed]

114. Van Avondt, K.; van der Linden, M.; Naccache, P.H.; Egan, D.A.; Meyaard, L. Signal Inhibitory Receptor on Leukocytes-1 Limits the Formation of Neutrophil Extracellular Traps, but Preserves Intracellular Bacterial Killing. J. Immunol. 2016, 196, 3686-3694. [CrossRef] [PubMed]

115. Knight, J.S.; Subramanian, V.; O’Dell, A.A.; Yalavarthi, S.; Zhao, W.; Smith, C.K.; Hodgin, J.B.; Thompson, P.R.; Kaplan, M.J. Peptidylarginine deiminase inhibition disrupts NET formation and protects against kidney, skin and vascular disease in lupus-prone MRL/lpr mice. Ann. Rheum Dis. 2015, 74, 2199-2206. [CrossRef] [PubMed]

116. Lewis, H.D.; Liddle, J.; Coote, J.E.; Atkinson, S.J.; Barker, M.D.; Bax, B.D.; Bicker, K.L.; Bingham, R.P.; Campbell, M.; Chen, Y.H. Inhibition of PAD4 activity is sufficient to disrupt mouse and human NET formation. Nat. Chem. Biol. 2015, 11, 189-191. [CrossRef] [PubMed]

117. Li, W.X.; Wang, F.; Zhu, Y.Q.; Zhang, L.M.; Zhang, Z.H.; Wang, X.M. Inhibitors of nitric oxide synthase can reduce extracellular traps from neutrophils in asthmatic children in vitro. Pediatr. Pulmonol. 2020, 55, 68-75. [CrossRef] [PubMed]

118. Sollberger, G.; Choidas, A.; Burn, G.L.; Habenberger, P.; Di Lucrezia, R.; Kordes, S.; Menninger, S.; Eickhoff, J.; Nussbaumer, P.; Klebl, B. Gasdermin D plays a vital role in the generation of neutrophil extracellular traps. Sci. Immunol. 2018, 3, eaar6689. [CrossRef]

119. Zheng, W.; Warner, R.; Ruggeri, R.; Su, C.; Cortes, C.; Skoura, A.; Ward, J.; Ahn, K.; Kalgutkar, A.; Sun, D. PF-1355, a mechanism-based myeloperoxidase inhibitor, prevents immune complex vasculitis and anti-glomerular basement membrane glomerulonephritis. J. Pharmacol. Exp. Ther. 2015, 353, 288-298. [CrossRef]

120. Parker, H.; Dragunow, M.; Hampton, M.B.; Kettle, A.J.; Winterbourn, C.C. Requirements for NADPH oxidase and myeloperoxidase in neutrophil extracellular trap formation differ depending on the stimulus. J. Leukoc Biol. 2012, 92, 841-849. [CrossRef]

121. Cianchi, F.; Cortesini, C.; Fantappie, O.; Messerini, L.; Schiavone, N.; Vannacci, A.; Nistri, S.; Sardi, I.; Baroni, G.; Marzocca, C. Inducible nitric oxide synthase expression in human colorectal cancer: Correlation with tumor angiogenesis. Am. J. Pathol. 2003, 162, 793-801. [CrossRef]

122. Zafirellis, K.; Zachaki, A.; Agrogiannis, G.; Gravani, K. Inducible nitric oxide synthase expression and its prognostic significance in colorectal cancer. APMIS 2010, 118, 115-124. [CrossRef]

123. Gao, Y.; Zhou, S.; Xu, Y.; Sheng, S.; Qian, S.Y.; Huo, X. Nitric oxide synthase inhibitors $1400 W$ and L-NIO inhibit angiogenesis pathway of colorectal cancer. Nitric Oxide 2019, 83, 33-39. [CrossRef] 
124. Menegazzo, L.; Scattolini, V.; Cappellari, R.; Bonora, B.M.; Albiero, M.; Bortolozzi, M.; Romanato, F.; Ceolotto, G.; Vigili de Kreutzeberg, S.; Avogaro, A. The antidiabetic drug metformin blunts NETosis in vitro and reduces circulating NETosis biomarkers in vivo. Acta Diabetol. 2018, 55, 593-601. [CrossRef]

125. Zhang, S.; Zhang, Q.; Wang, F.; Guo, X.; Liu, T.; Zhao, Y.; Gu, B.; Chen, H.; Li, Y. Hydroxychloroquine inhibiting neutrophil extracellular trap formation alleviates hepatic ischemia/reperfusion injury by blocking TLR9 in mice. Clin. Immunol. 2020, 216, 108461. [CrossRef]

126. Xiao, Y.; Cong, M.; Li, J.; He, D.; Wu, Q.; Tian, P.; Wang, Y.; Yang, S.; Liang, C.; Liang, Y. Cathepsin C promotes breast cancer lung metastasis by modulating neutrophil infiltration and neutrophil extracellular trap formation. Cancer Cell 2021, 39, 423-437.e7. [CrossRef]

127. Smith, C.K.; Vivekanandan-Giri, A.; Tang, C.; Knight, J.S.; Mathew, A.; Padilla, R.L.; Gillespie, B.W.; Carmona-Rivera, C.; Liu, X.; Subramanian, V. Neutrophil extracellular trap-derived enzymes oxidize high-density lipoprotein: An additional proatherogenic mechanism in systemic lupus erythematosus. Arthritis Rheumatol. 2014, 66, 2532-2544. [CrossRef] [PubMed]

128. Fuchs, T.A.; Brill, A.; Duerschmied, D.; Schatzberg, D.; Monestier, M.; Myers, D.D., Jr.; Wrobleski, S.K.; Wakefield, T.W.; Hartwig, J.H.; Wagner, D.D. Extracellular DNA traps promote thrombosis. Proc. Natl. Acad. Sci. USA 2010, 107, 15880-15885. [CrossRef]

129. Manda-Handzlik, A.; Bystrzycka, W.; Cieloch, A.; Glodkowska-Mrowka, E.; Jankowska-Steifer, E.; Heropolitanska-Pliszka, E.; Skrobot, A.; Muchowicz, A.; Ciepiela, O.; Wachowska, M. Nitric oxide and peroxynitrite trigger and enhance release of neutrophil extracellular traps. Cell Mol. Life Sci. 2020, 77, 3059-3075. [CrossRef] 